\title{
Beberapa Permasalahan Ketenagakerjaan Dan Perspektif Pengembangan SDM : Analisis Sektor Industri
}

\author{
Oleh : Syafaruddin Alwl
}

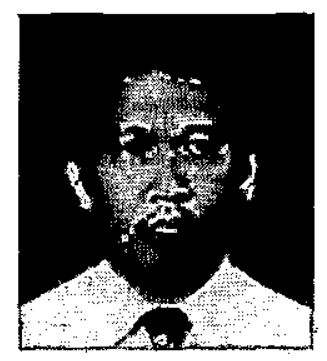

SyafaruddIn Alwl, lahir di Baturaja pada tanggal 16 Januari 1947, adalah Lektor pada Fakultas ekonomi UII. Pernah menjabat sebagai Dekan pada Fakultas tersebut selama'tigaperiode yaitu tahun 1982-1988. Pada tahun 1973 s/d 1978 menjadi Ketua L'PPM pada Fakultas yang sama sehingga sering melakukan kerja sama dalam pembinaan koperasi derigan berbagai instansi baik swasta maupun pemerintah. Pada tahun 1986, diundang oleh Australia Nasional University untuk menulis buku tentang studi pembangunan. Aktif mengikuti Seminar baik nasional maupun Internasional.

\section{Pendahuluan}

Berdasarkan sejarah, pembangunan ekonomi di Eropa Barat dan Amerika Utara seringkali .dijelaskan sebagai pengalihan aktivitas ekonomi yangberkesinambungan, migrasi dari desa ke kota baik dalam maupunantarnegara darikesempatan kerja terbuka pada saat industri mulai berkembang.

Pada saat yang sama, teknologi penghemat tenaga kerja diketemukan sehingga mengurangi permintaān tenaga kerja. Kombinasi kedua gejala tersebut memungkinkan negara barat melakukan transfer sumber daya manusia dari desa ke kota secara tertib dan efektif. Berdasarkan pengalaman ini banyak ahli ekonomi pembanguunan berpendapat bahwa pembangunan ekonomi di dunia ketiga harus dilakukan dengan mempercepat pertumbuhan industri. Tetapi sayang, berdasarkan pengalaman pula, strategi industrialisasi sering gagal mengulangi sukses masa lampau (Todaro, 1987). Optimisme tentang kemampuan sektor $\therefore$ industri terutama industri modem untuk menyerap tenaga kerja yang lebih baik temyatatidak terpenuhi.Kegagalan industri modern untuk menyediakan kesempatan kerja seperti yang diharapkan, terjadi di banyak negara berkembang seperti terlihat pada tabel 1 . 
Tabel 1

Industrialisasi dan Ketenagakerjaan di Negara Berkembang

\begin{tabular}{lcc}
\hline Negara & $\begin{array}{c}\text { Pertumbuhan } \\
\text { Qutput Manufaktur } \\
\text { Tahunan }\end{array}$ & $\begin{array}{c}\text { Pertumbutian } \\
\text { Kesempatan Kerja } \\
\text { Gektor Manufaktur }\end{array}$ \\
\hline India & 5,9 & 5,3 \\
Pakistan & 12,3 & 2,6 \\
Philipina & 6,1 & 4,8 \\
Thailand & 10,7, & $-12,0$ \\
Mesir & 11,2 & 0,7 \\
Nigeria & 14,1 & 5,3 \\
Brazilia & 6,5 & 1,1 \\
Panama & 12,9 & 7,4 \\
& & 1 \\
\hline
\end{tabular}

Suberi Todaro, yang dikutip dari David Morametz, Eaployaent Inplication of Industrialization Developing Countries, Econouic Journal B4.

Dari data tersebut dapatdilihatbahwa kebanyakannegaraberkembangmengalami pertumbuhan outputmanufakturlebih besar daripadapertumbuhan penyediaanlapangan kerja. Ini berarti perkembangan sektor industri saja tidak cukup untuk menyelesaikan masalah ketenagakerjaan. Menurut Todaro, kegagalan tersebut disebabkanolehnegara-negaraberkembang hanya mempekerjakan sekitar $10 \%-20 \%$ saja dari seluruh tenaga kerja. Pada sektor manufaktur hanya $20 \%$ dari seluruh tenaga kerja, yang berarti sektor tersebut perlu meningkatkan penyediaan lapangan kerja sebesar $15 \%$, guna menyerap pertambahan tenaga kerja sebesar $3 \%$ per tahun $(0,2 \times 0,15)$.

Indonesiapada pembangunan jangka panjang tahap ke II (PJPT II), juga memasuki tahap proses industrialisasi dengan tetap menjaga keseimbangan pembangunan antara sektor pertanian dan sektor industri. Dalam kaitan dengan apa yang dikemukakan oleh Todaro tersebut, pertanyaan penting yarig akan dibahas adalah, apakah dalam PJPT II nanti, proses tinggal landas yang akan dilalui mampu menyediakan kesempatan kerja yang lebih luas sehingga pengangguran dapat dikurangi pada tingkat yang serendah mungkin ?. Berkaca pada pengalaman negara berkembang lainnya, untuk mengimbangi kebutuhan tenaga kerja pada PJPT II yang mana pada saat itu peran sektor manufaktur menjadi semakin meningkat terhadap pendapatan domestik bruto (PDB), bagaimana sebaiknya pengembangan sumber daya manusia dilakukan agartersedia tenaga kerja terdidik yang mampu menunjang kebutuhan tersebut?

Pemahaman mengenai sumber daya 
manusia sebenamya tidak hanya meliputi jumlah penduduk yang besar dan tingkat pendidikan saja, tetapi menyangkut pula mengenai persepsinya terhadap pekerjaan, pandangan kebudayaannya dan keinginan untuk mengembangkan kualitas diri. Pembahasan sumber daya manusia ini dibatasi dalam pengertian jumlah tenaga kerja yang tersedia dan kualitasnya. Pembahasan mengenai aspek sumber daya ini dikaitkan dengan aspek ketenagakerjaan adalah penting mengingat pertumbuhan ekonomi tidak hanya dipengaruhi oleh besamya investasi dan faktor teknologi melainkanjugaditentukan oleh jumlah dan kualitas penduduk angkatan kerjanya (technical skill).

\section{Kesempatan Kerja dan Pengangguran}

Kesempatankerjadan pengangguran merupakan dua sisi mata uang yang tidak hanya melanda negara-negara yang sedang berkembang (NSB), tetapi juga melanda negara-negara maju yang dikenal sebagai negaraindustri. Ini menunjukkan persoalan ketenagakerjaan dan pengangguran tidak hanya menyangkut kemampuan suatu negara atau pemerintahuntuk menyediakan lapangan pekerjaan, melainkan juga menyangkut kemampuan setiap individu yang tergolong angkatan kerja untuk menciptakan pekerjaan bagi dirinya. Disini perspektif pengembangan sumber daya menjadi bagian penting dari proses pembangunan ekonomi. Proses pembangunan ekonomi dalam kaitan ini berarti meliputi dua pengertian yaitu peningkatan pertumbuhan ekonomi (out put) dan perkembangan ekonmi (peningkatan jumlah unit-unit ekonomi) yang mampu menyediakan lapangan kerja baru.

Apa yang diharapkan terjadi pada PJPT II khususnya penyediaan lapangan kerja dan penyediaan tenaga kerja yang memenuhi kualifikasi kebutuhan, tidak lepas dari kondisi obyektif ketenagakerjaan yang telah dicapai selama PJPT I, yang dapat dilihat dari data berikut :

Tabel 2

Penduduk dan Angkatan Kerja Indonesia 1971, 1980, 1990

\begin{tabular}{cccc} 
& & Pertumbuhan & Angkatan \\
Penduduk & Penduduk & Kerja & $\begin{array}{c}\text { Pertumbuhan } \\
\text { Angkatan Kerja }\end{array}$ \\
Tahun $(000)$ & $(\%)$ & $(000)$ & $(\%)$ \\
\hline
\end{tabular}

$\begin{array}{ccccc}1971 & 118.368 & 1 & 41,261 & \\ 1980 & 146.777 & 2,4 & 52,153 & 2,6 \\ 1990 & 179.248 & 2,0 & 74.395 & 3,6\end{array}$

Sunber: Biro Pusat Statistik , Sen5us Penduduk , 1971, 1980 dan 1990, 
Berdasarkan data tersebut, dapat diketahui pada dekade tahun 1980-1990, jika diamati Indonesia mengalami pertumbuhan angkatan kerja yang paling tinggi yang pernah terjadi. Selama periode itu angkatan kerja meningkat sebesar 3,6 \% per tahun. Secara absolut angkatan kerja bertambah rata-rata 2,2 juta per tahun sehingga sampai dengan tahun 1990, penduduk angkatan kerja telah mencapai 74,4 juta. Ședangkan pertumbuhan penduduk turun menjadi $2 \%$. Seberapa besar penyerapan tenaga kerja oleh sektor industri khususnya industri nonmigas, dapat dilihat dari tabel 3.
Dalam perbandingan antar kelompok, kelompok aneka industri menyerap tenaga kerja lebih tinggi dan kemudian diikuti oleh keleompok industri kecil.

Namun demikian untuk memperoleh gambaran yang lebih jelas mengenai kondisi obyektif yang telah dihadapi selama PJPT I, perlu ditinjau pula besamya pengangguran yang terjadi. Berdasarkan sensus tahun 1990 tidak banyak perubahan selama 10 tahun terakhir ini yang menunjukkan angka separuh pengangguran yaitu yang bekerja kurang dari 35 jam per minggu, sebesar 27,8 juta atau $38,7 \%$ dari seluruh angkatan

Tabel 3

Penyerapan Tenaga Kerja Sektor Industri

\begin{tabular}{|c|c|c|c|c|c|}
\hline Kelompok & Industri & 1988 & 1989 & 1990 & 1991*) \\
\hline & & · & & & \\
\hline Aneka & Industri & , 539.529 & 814.663 & 1.381 .513 & 1.804 .364 \\
\hline $\begin{array}{l}\text { Industri } \\
\text { Industri }\end{array}$ & $\begin{array}{l}\text { Kimia Dasar } \\
\text { Mesin, }\end{array}$ & 22.907 & 38.545 & 51.538 & 56.182 \\
\hline $\begin{array}{l}\text { Logam Das } \\
\text { Elektroni }\end{array}$ & $\begin{array}{l}\text { gar dan } \\
\text { Ika }\end{array}$ & 44.104 & 60.178 & 99.102 & 149.881 \\
\hline Industri & Kecil & 363.351 & 601.012 & 841.912 & 1.027 .814 \\
\hline
\end{tabular}

Suabers Miro Pusat Btatiotik, diolah Deparind, 1992.

1) Angka sesentara.

Data tabel 3 tersebut menunjukkan sejak kerja. Pada tahun 1980, angka tersebut tahun 1988 , terjadi peningkatan penyerapan sebesar $38 \%$, sebagaimana terlihat pada tenaga kerja pada setiapkelompokindustri. tabel 4. 
Tabel 4

Penduduk 10 tahun ke atas yang bekerja kurang dari 35 jam seminggu menurut sektor 1980-1990

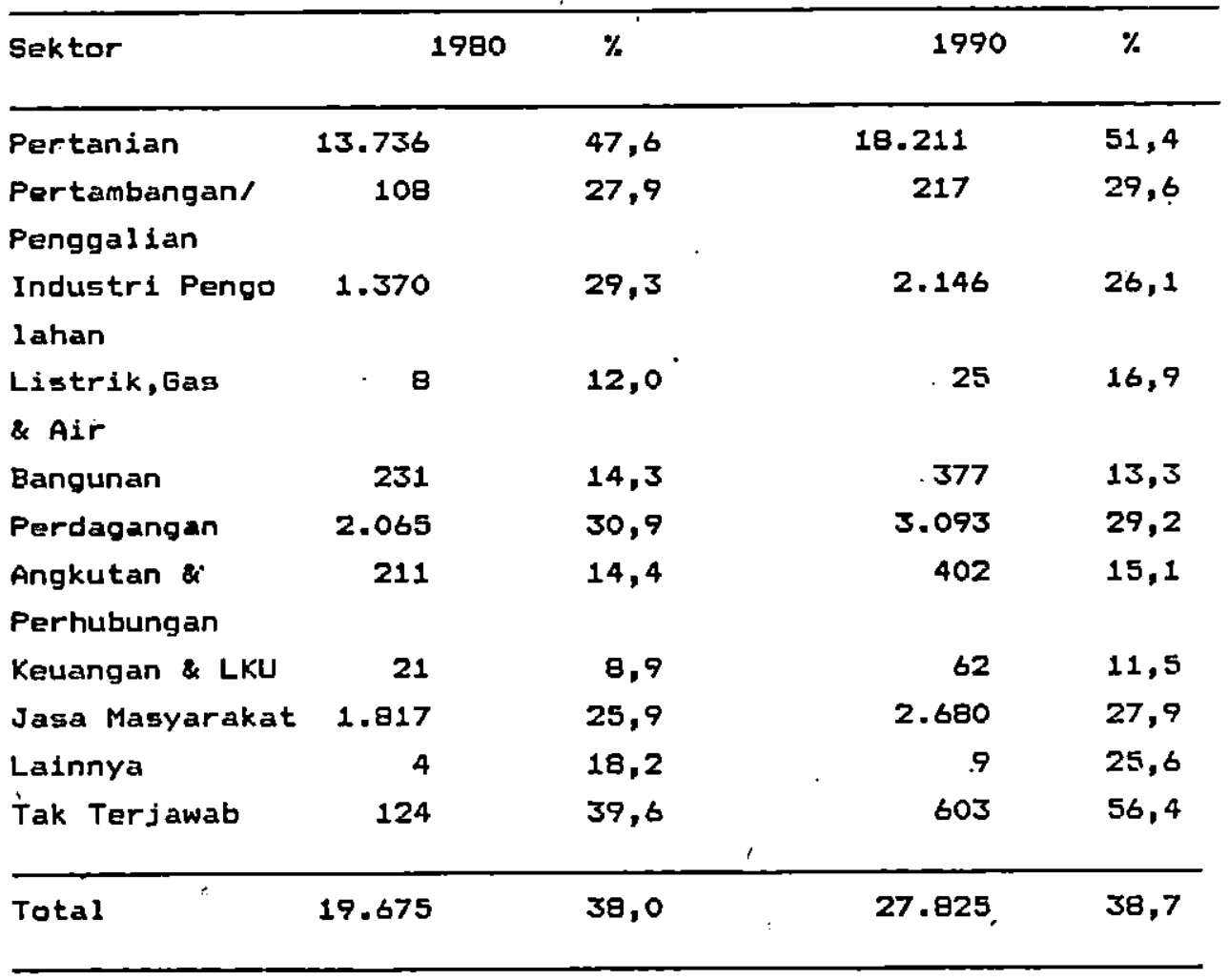

\section{Susber: Biro Pusat Statistik.}

\section{Dinodifitasi}

Dengan perhitungan yang menunjukkan adanya separuh pengangguran, jika tidak dilakukan usahausaha pembangunan yang berorientasi pada penyerapan tenaga kerja maka sangat mungkin terjadi, keadaan ini berkembang menjadi pengangguran terbuka (open employment). Oleh sebab itu masalah pokok yang akandihadapi pada PJPT II, khususnya mengenai ketenagakerjaan, adalah pengangguran yang mungkin semakin meningkat pada PJPT II. Menurut Sayuti Hasibuan (1992), angka separuh pengangguran sebesar 27,8 juta orang itu dapat menjadi 18,2 juta orang jika diterjemahkan menjadi pengangguran terbuka. Jumlah ini bisa meningkatmenjadi 20,2 juta orang pada Pelita VI (berdasarkan rumus tertentu). Dan jika tabel 4 tersebut diterjemahkan menjadi perekonomian desa dan kota (tabel 5), maka pada tahun 1980, separuh pengangguran berada di desa sebesar 42,8 \%, sedangkan di kota $18,4 \%$. Pada tahun 1990, di desa sebesar 45,1\%, sedangkan di kota $21,1 \%$. Ini berarti tingkat pengangguran di kota selama 10 tahun ini telah berkembang menjadi dua kali lipat dari pada di desa. 


\section{Tabel 5}

Penduduk 10 tahun ke atas yang bekerja kurang dari 35 jam seminggu menurut daerah

\begin{tabular}{l|c|c|c|c}
\hline \multirow{2}{*}{ Tahun } & \multicolumn{3}{|c|}{ Desa } & \multicolumn{3}{c}{ Kota ; } \\
\cline { 2 - 5 } & Jumlah & $\%$ & Jumlah & $\%$ \\
\hline 1980 & 17.911 & 42,8 & 1.764 & 18,4 \\
1990 & 23.762 & 45,1 & 4.062 & 21,1 \\
\hline
\end{tabular}

Sumber : Biro Pusat Statistik dimodifikasj

Tingkat pengangguran di desa yang lebihtinggi daripada di kotamenurutLewis (1970), dapat diatasi dengan pemindahan secara bertahap tenaga kerja ke kota melalui pembangunan industri di perkotaan. Lewis yang kemudian diperbaharui oleh Gustav Ranis dan Fei, membagi ekonomi menjadi dua bagian yaitu sektor substitusi pedesaan yang tradisional dengan tingkat produktivitas dan sektor industri modern di perkotaan dengan produktivitas yang tinggi. Pemindahan' tenaga kerja ini dan pertumbuhan pekerjaan di perkotaan akan menciptakan perluasan output dalam sektor modern. Jika persektif Lewis ini akan dipertimbangkan, maka asumsi yang dipakai adalah bahwa keuntungan yang diperoleh di sektor modern tidak - dibelanjakan dalam bentuk peralatan yang mengurangi tenaga kerja. Kemudian, oleh karena tenaga kerja di pedesaan itu boleh dikatakan keahliannya tidak sesuai dengan tuntutan keahlian di sektor modern, maka investasi di bidang modal sosial overhead (antara lain pendidikan), perlu dilakukan. Jika tidak maka surplus tenaga kerja di pedesaan kemudian pindah ke perkotaan, akanmenjadipenganggurbarudiperkotaan. Ini jelas tidak menyelesaikan masalah.

\section{Prospek Lapangan Kerja PJPT II}

Pembangunan industri nasional diselenggarakan berpedoman kepada Trilogi Pembangunan yaitu pembangunan industri diiringi dengan penyebaran dalam arti luas. Pertany'aan yang sekarang timbul adalah bagaimana prospek lapangan kerja pada PJPT II khususnya di sektor industri. Besarkecilnya potensi tersedianyalapangan kerja di sektor industri tergantung pada tingkat pertumbuhan industri itu sendiri. Berdasarkan data yarig tersedia, dalam dekade 10 tahun yaitu 1980-1990, perkembangan daya serap sektor industri relatif rendah $(1,6 \%)$, yang dapat dilihat dari tabel 6 berikut : 
Tabel 6

Daya Serap Tenaga Kerja Sektor Industri dan Perbandingannya dengan Non Industri

\begin{tabular}{lcc}
\hline Tahun & Industri & Non Industri \\
\hline 1980 & $20,9 \%$ & $79,0 \%$ \\
1985 & $20,5 \%$ & $79,5 \%$ \\
1990 & $22,5 \%$ & $77,5 \%$ \\
\hline
\end{tabular}

Sumber : Sayuti Hasibuan, Makalah yang disampaikan pada Seminar ISEI, 1992 di Banjarmasin

Berdasarkan data tersebut, maka proyeksi untuk yang akandatangbagi sektor industri, nampaknya sektor industri tidak akan mampu dibebani tanggung jawab untuk menyerap tenaga kerja yang lebih banyak. Secara keseluruhan sektor industri hanya mampu menyerap sekitar $20 \%$ saja dari seluruh tenaga kerja yang tersedia dalam 10 tahun itu. Daya serap yang rendah ini disebabkạn laju pertumbuhan industri yang relatif tidak banyak meningkat dan bahkanpada tahun 1991 menurundari 12,08 $\%$ menjadi $11,03 \%$. Tetapi dilihat dari sumbangannya terhadap PDB, peranan sektor industri meningkat dari $20,32 \%$ menjadi $22,22 \%$. Ini berarti terjadi kenaikan efisiensi pada sektor industri.

\section{Strategi Pengembangan Sumber Daya Manusia}

Beranjak dari kondisi seperti yang telah diuraikan maka persoalan pengembangan sumber daya manusia sebagai sumber peningkatan produktivitas nasional tidak hanya diarahkan kepada penyediaan ketrampilan dan keahlian yang menunjang permintaan tenaga kerja semata, tetapi diarahkan kepada peningkatan sumber dayá yang mampu menciptakan pekerjajan bagi dirinya sendiri, mengingat pertumbuhan lapangan kerja yang tersedia tidak lebih besar dari pada pertumbuhan penduduk angkatan kerja. Bagi sektor industri, pengembangan sumber daya manusia harus diarahkan pada daya dukung profesional dalam melalui suatu program pendidikan yang mampu memenuhi tuntutan tenaga kerja di sektor industri.

Para pakarumumnya sepakat bahwa masalah pembangunan ekonomi bukan saja ditentukan oleh sumber daya berupa modal fisik atau material semata tetapi yang tidak kalah pentingnya adalah sumber daya manusia sebagai pengelola kekayaan alam. Herbison (1973) mengatakan :

"Sumber daya manusia ..... merupakan modal dasar dari kekayaan suatu bangsa. Modal fisik dan sumber daya alam hanyalah faktorproduksi yang bersifat pasif, manusia adalah agen-agen yang aktif mengumpulkan modal, mengeksploitasikan sumber-sumber alam, membangun organisasi sosial, ekonomi dan politik dan melaksanakan pembangunan nasional. Jelaslah suatu negara yang tidak mengembangkan keahlian dàn pengetahuan rakyatnya dan 
tidak menggunakan mereka secara efektif dalam ekonomi nasional maka untuk selanjutnya tidak akan dapat mengembangkan apapun".

Dengan demikian bagi Indonesia adalah tepat untuk meletakan masalah sumber daya manusia pada urutan pertama yang harus dikembangkan untuk mampu menjawab tantangan-tantangan pembangunan ekonomi pada PJPTII. Yang masih menjadi persoalan adalah tentang model pengembangan yang tepat untuk menghasilkan kualitas tenaga kerja yang diharapkan.

Hirshcman, dalam teori ketidakseimbangannya, lintasan pembangunan dapat dilakukan dengan melalui tekanan pada investasi modal overhead sosial (MOS), untuk kemudian mendukung investasi kegiatan langsung produktif (KLP). Beranjak dari pendapat. ini bagi Indonesia sudah tepat untuk mengembangkan program pendidikan ketrampilan dan sebagainya yang diarahkan untuk mampu mendukung kebutuhan tenaga ke'rja pada investasi KLP.

Ada dua model yang pada umumnya ditempuh untuk mengembangkan pendidikan yaitu, pertama, memperluas sistem pendidikan formal dengan perubahan yang disesuaikan dengan perkembangan. Model ini merupakan model yang sekarang berlangsung dan telah terbukti justeru menimbulkan penganggurän karena menghadapi struktur kelembagaan pasar tenaga kerja yang memiliki tuntutan lebih bersifat technical skill. Kedua, mengadakan reformasi keseluruhan, sistem pendidikañ 'dengan perubahan terhadap kondisi-kondisi permintaan dan penawaran untuk sekolah berdasarkan kurikulum yang. relevan dengan kebutuhan pasar tenaga kerja.

\section{Penutup}

Berdasarkan fakta dan analisis seperti yang telah dikemukakan, masalah ketenagakerjaan pada PJPT II, khususnya mengenai penyediaan lapangan kerja, jelas tidak mudah untuk dijawab. Namun paling tidak dapat dikemukakan bahwa kesempatan kerja akan lebih meningkat pada PJPT I, walaupun peningkatan itu akan terjadi secara gradual. Dan untuk mendukungpermintaan pasartenaga negara di sektor industri, diperlukan reformasi sistem pendidikan yang mengacu pada kurikulum yang relevan dengan kebutuhan tenaga kerja.

\section{Referensi}

FeiandRanis, 1964, Development of The Labor Surplus Economy. Theory and Policy, Yale University Press.

Lewis, 1955, The Theory of Economic Growth. Sayuti Hasibuan, 1992, Makalah Tentang Beberapa Pemikiran Mengenai Industialisasi, Industri Pertanian dan Lapangan Kerja PJPT II.

Todaro, Pembangunan Ekonomi di Dunia Ketiga, 1987, PenerbitErlangga Jakarta. 